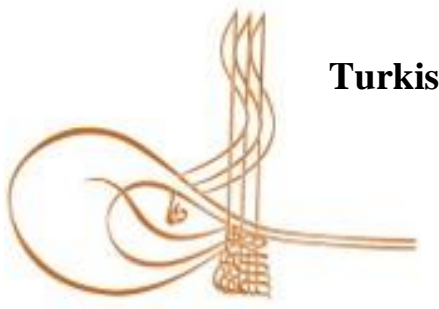

www.turkishstudies.net/appliedsciences
eISSN: 2667-5633

Research Article / Araștırma Makalesi

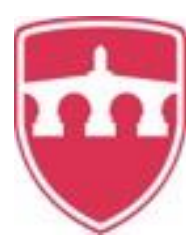

INTERNATIONAL

BALKAN

UNIVERSITY

Sponsored by IBU

\title{
İnternet Haber Sitelerinin Kullanılabilirliğinin Göz İzleme Teknikeriyle Analizi
}

\author{
Analysis of the Usability of Internet News Sites with Eye Tracking Techniques
}

\author{
İbrahim Etem Zinderen*
}

\begin{abstract}
The aim of this study is to identify the usability issues that arise in relation to news presentation on the Internet, and to provide suggestions for eliminating the problems and making Internet news sites more useful. For this purpose, the usability of Internet news sites is presented in the study in the user axis with the help of eye monitoring device. Within the scope of the study, Alexa and Similarweb data were compared over criteria such as total number of visits per month, daily time spent on site and number of pageviews per visitor per month, and three news sites with similar characteristics were selected among the top 10 most clicked news sites according to August-September 2019. In this context, hurriyet.com.tr, ensonhaber.com and haber7.com news sites were determined with purposeful/judicial sampling technique for the study. The study was conducted with a group of 10 students including 5 male and 5 female students. Participants were asked to perform certain tasks which were accessing last minute news, openning news archive, sharing news and commenting on the news on these three news sites that were determined. While the participants performed these tasks, the eye movements and the times of performing the tasks were recorded with the eye monitoring device. At the end of the study, the participants were asked their opinions about the usability of the Internet news sites on which they performed the tasks. The data obtained with this study were analyzed with descriptive analysis method, the usability problems were identified and suggestions were made to make the news sites more useful.
\end{abstract}

Structured Abstract: Moving journalism to the online environment has brought along many positive developments in terms of journalism but has also caused many ethical problems. For example, the fact that the news portals are full of advertisements and the appearance of pop-ups tire the user in terms of reaching the news, and the design of the news portals often makes it difficult to reach the desired information. In the study, which aims to identify the usability problems that arise in online journalism and to offer suggestions to eliminate these problems and to make the online news portals more useful, the usability of the online news portals was revealed on the user axis with the help of an eye tracking device.

In order to determine the tasks to be given to the participants through news portals before the eyetracking stage of the study, a preliminary study including open-ended questions was conducted in determining

\footnotetext{
* Dr. Öğr. Üyesi, Atatürk Üniversitesi, İletişim Fakültesi, Gazetecilik Bölümü Asst. Prof. Dr. Atatürk University, Faculty of Communication, Department of Journalism ORCID 0000-0003-2921-4857

ibrahim.zinderen@atauni.edu.tr

Cite as/ Atıf: Zinderen, İ.E. (2020). İnternet haber sitelerinin kullanılabilirliğinin göz izleme teknikeriyle analizi, Turkish Studies-Applied Sciences, 15(1), 139-155. https://dx.doi.org/10.29228/TurkishStudies.40477

Received/Geliş: 08 January/Ocak 2020

Accepted/Kabul: 25 March/Mart 2020

Checked by plagiarism software

Copyright $(\mathrm{C}$ INTAC LTD, Turkey 
the purpose of the participants entering the news portals, what they do the most on the news portals and the areas they look the most in a news portal. The questions in the preliminary study were directed to 20 students who are currently receiving postgraduate education. In this context, task categories such as 'reaching the breaking news, opening the news archive, sharing the news and commenting on the news' were determined in accordance with the purpose of the study. Before proceeding to the stage where the eye tracking device is used, a pilot study was conducted with 2 female and 2 male participants. In this process, a planning was made regarding the duration of the experiment, whether the news portals will be displayed one after the other and how this process will work.

In order to conduct the study, the students of Ataturk University, Institute of Social Sciences, Department of Journalism were reached through their supervisors, and among these students, a total of 10 students who are on the course and thesis stages, between the ages of 25-30, 5 women and 5 men, were determined on a voluntary basis. Participants have similar features in terms of age and educational status. Based on this, the participants were assumed to have a similar level of perception. It was particularly paid attention to the fact that the participants in the study were not using the determined news portals.

Three news portals, ensonhaber.com, haber7.com and hurriyet.com.tr, were selected among the 10 most clicked news portals, according to the data of August-September 2019, which are in accordance with the determined task categories and have similar features regarding this aspect. At this stage, eye tracking device, RED250 computer and screen-based eye tracking module from eye tracking software were used. Whether the participants were able to perform 6 basic tasks with each news selected as an example and the duration of completion of these tasks were measured. On the other hand, the first point of gaze (Bee Swarm), the eye scanning path (Scan Path) and the click points of the participants were determined with the eye tracking device in order to perform these tasks. After the experiment, the opinions of the participants regarding the usability of the online news portals on which they performed their tasks were recorded with the interview form.

When it is evaluated in terms of Bee swarm and Scan path data, it was seen that the advertisement in the hurriyet.com.tr attracted the attention of the large part of the participants by its location and size and it was the first point of gaze. On the other hand, it was detected that there are saccades towards the advertisement and pop-up sections in the users' eye movements. While the movement that attracts the attention of the user with this aspect causes the eye to shift from news texts and visuals, the necessity of closing pop-ups causes deviations in click points and prolongs the task periods.

In general, considering the way of scanning the eye, the first point of gaze, the duration of the tasks and the data of the interviews, it was seen that the most negative factor on the usability of the news portals is advertisements. The fact that advertisements are animated, occupy a lot of space on the page, and especially the pop-up ads on the news portals are seen as the biggest obstacle to the preference of the news portal. In addition, pop-ups on news portals attract attention as another factor that users are disturbed by and thus affect the usability negatively. Therefore, it is inferred that the complex appearance of the interface, the use of large visuals, the distraction of large-sized dynamic advertisements, and the presence of a large number of sliders cause usability issues on news portals.

The fact that commenting in the comments section which is generally at the lower section of the news portals addressed during the experiment requires membership, the conditions of acceptance and the non-visible checkbox also create usability issues on the portals. While it is considered important that there is no membership requirement for commenting in terms of providing interaction and accordingly democratic participation in news portals, the comment section should also have a design based on fast and easy use. The fact that the comments section is just below the news text will make it easier to comment.

One of the biggest advantages of information technologies on journalism is that the news can be archived and stored. In this regard, the creation of archives in news portals will be functional for users who want to access that news later. Accordingly, the fact that the news archive, which is one of the usability issues, is not easily found or the problem of not finding news in the archive is seen as an important problem for online news portals. In this context, it should be noted that the archive should have a more visible and functional structure in terms of accessibility and preference.

Keywords: Journalism, Internet News Sites, Usability, Eye Tracking, Human Computer Interaction (HCI) 
Öz: $\mathrm{Bu}$ çalışmanın amacı internet haber sitelerinde ortaya çıkan kullanılabilirlik sorunlarını tespit etmek, sorunların ortadan kaldırılması ve internet haber sitelerinin daha kullanışlı hale getirilebilmesi için öneriler sunmaktır. Bu amaç doğrultusunda çalışmada internet haber sitelerinin kullanılabilirliği, göz izleme cihazı yardımıyla kullanıcı ekseninde ortaya konulmaktadır. Çalışma kapsamında aylık toplam ziyaret edilme sayısı, sitede günlük zaman geçirme ve ziyaretçi başına günlük sayfa görüntüleme sayısı gibi kriterler üzerinden Alexa ve Similarweb verileri karşılaştırılarak Ağustos-Eylül 2019 verilerine göre en çok tıklanan 10 haber sitesi arasından oluşturan görev kategorilerine göre benzer özelliklere sahip üç haber sitesi seçilmiştir. Bu çerçevede çalışma için amaçlı örneklem tekniği ile hurriyet.com.tr, ensonhaber.com ve haber7.com haber siteleri belirlenmiştir. Çalışma 5 erkek ve 5 kadın olmak üzere 10 kişilik lisansüstü öğrenci grubu ile gerçekleştirilmiştir. Katılımcılardan, belirlenen üç haber sitesinde son dakika haberlerine ulaşma, haber arşivini açma, haberi paylaşma ve habere yorum yapma görevlerini gerçekleştirmeleri istenmiştir. Katılımcılar bu görevleri gerçekleştirirken göz hareketleri ve görevi gerçekleştirme süreleri göz izleme cihazıyla kayıt altına alınmıştır. Çalışma sonunda katılımcılara görevleri gerçekleştirdikleri internet haber sitelerinin kullanılabilirliğine ilişsin görüşleri sorulmuştur. Bu çalışma ile elde edilen veriler betimsel analiz yöntemi ile analiz edilmiş ve ortaya çıkan kullanılabilirlik sorunları tespit edilerek haber sitelerinin daha kullanışlı hale getirilebilmesi için önerilerde bulunulmuştur.

Anahtar Kelimeler: Gazetecilik, İnternet Haber Siteleri, Kullanılabilirlik, Göz İzleme, İnsan Bilgisayar Etkileşimi (İBE)

\section{Giriş}

İletişim teknolojilerinde yaşanan gelişmeler haber yapım ve sunum şeklinde köklü değişiklikler yaratmıştır. 1969'da ARPANET projesi kapsamında dört bilgisayarın birbirine bağlanması ile internetin ilk şekli ortaya çıkmış, 1989 yılında geliştirilen 'WWW' (World Wide Web) teknolojisi ile de gazeteler kısa sürede internet ortamında varlık göstermeye başlamıştır (Toruk, 2008: 268-269). İnternet gazeteleri ilk olarak ABD'de 1995 yılında ortaya çıksa da o dönemde internet gazeteciliği yalnızca matbu gazetelerin internet ortamına aktarılması şeklinde gerçekleştirilmiştir. Sonraki y1llarda ise teknolojik gelişmelere bağlı olarak haberler, internet ortamına özgü olarak üretilirken yeni medyanın tüm imkânlarından yararlanılarak sunulmaya başlanmıştır (Tokgöz, 2013: 112-113). Özellikle O'Reilly tarafindan popüler hale getirilen Web 2.0 teknolojilerinin haber açısından en görünür etkisi çevrimiçi haberlerin ortaya çıkışı olmuştur. Web 2.0 ile birlikte çevrimiçi bir nitelik kazanan yeni medya ortamı erişilebilirlik, erişim hızı, mobilite gibi birçok özelliği ile haberin yapım ve sunum şekilleri üzerinde önemli değişiklikler yaratmıştır (Stanyer, 2009: 202). Bugün internet ortamında haberi sunmak için çokluortam (multimedya) ve hiperortam (hipermedya) gibi yeni iletişim ortamının sunduğu olanaklar etkin bir şekilde kullanılmaktadır.

Haberin internet ortamına taşındığı ilk zamanlardan günümüze internet gazeteciliği, gazetecilik faaliyetlerinin gerçekleştirildiği mecralar içerisinde başat konuma gelmiştir. Bu süreçte geleneksel medya kuruluşları internet haber siteleri açarak habercilik faaliyetlerini internet ortamında gerçekleştirmeye başlamıştır. Bu sitelere ek olarak zamanla pek çok alternatif haber sitesi ortaya çıkmıştır. Bugün ana akım haber siteleri, endeks siteleri, eleştiri ve yorum siteleri, paylaşım ve tartışma siteleri olarak gruplandırılan çok sayıda haber sitesi mevcuttur (Geray ve Aydoğan, 2010). Bununla birlikte yeni medya ortamında habere ilişkin pek çok sorun ortaya çıkmaktadır. Etik problemlerden sitelerin kullanılabilirlik sorunlarına kadar geniş bir yelpazeye yayılan bu sorunlar İnsan Bilgisayar Etkileşimi başta olmak üzere farklı açılardan ele alınabilmektedir.

1980'lerin başından itibaren kullanılan ve kökleri farklı disiplinlere uzanan İnsan Bilgisayar Etkileşimi (Human Computer Interaction) İBE (HCI) kavramı, kullanıcının bilgisayar ile etkileşimine ve bu etkileşim sürecindeki performansına işaret etmektedir. İnsan Bilgisayar Etkileşimi; insan, bilgisayar ve görevler ekseninde etkileşimli sistemlerin tasarlanmasını, 
uygulanmasını ve değerlendirilmesini içermektedir (Dix vd., 2004: 3-4). Bu açıdan İnsan Bilgisayar Etkileşimi, tasarım sürecinin önemli bir parçasını oluşturmaktadır.

Kullanılabilirkik testi ve kullanıcı deneyimi testleri, bir sistemin kapsamlı ve sistematik değerlendirmesini içermektedir. Değerlendirmenin temel amacı ise ilgili sistemin beklendiği gibi davranıp davranmadığının tespiti ve bu sistemin kullanıcı gereksinimlerini karşılayıp karşılamadığının test edilmesidir (Dix vd., 2004: 319). Göz izleme çalışmaları ekseninde incelenen siteye ilişkin çeşitli analizler yapılabilmektedir. Örneğin toplam ziyaret süreleri çerçevesinde en fazla ve en az hangi içeriğe bakıldığına ilişkin tespitler mümkün olmakta, çalışma amaçlarına göre belirlenen diğer ölçümlerle birlikte bu tespitler üzerinden arayüz ve kullanılabilirlik çıkarımları yapılabilmektedir (Males \& Setniker, 2019). Dolayısıyla kullanılabilirlik çalışmaları, İnsan Bilgisayar Etkileşimi çerçevesinde gerçekleştirilen, teknolojinin daha etkin ve kolay kullanımı için insana uygun hale getirilmesi tezine yönelik bir dizi araştırmayı içermektedir. Bu doğrultuda çalışma, insan bilgisayar etkileşimi bağlamında internet haber sitelerinin kullanılabilirliği üzerine odaklanmaktadır.

Teknolojik tabanlı gelişmelere bağlı olarak gazetecilik pratiklerinin değişimi, internet haber sitelerinin ve haberciliğinin yaygınlaşmasını sağlamıştır. Gazeteciliğin internet ortamına taşınması habercilik açısından pek çok olumlu gelişmeyi beraberinde getirmekle birlikte birçok etik sorun da doğurmuştur. $\mathrm{Bu}$ etik sorunların başında görüntüyle oynama, bilgi yanılsaması, sitelerin amacı dışında kullanılması, içeriğin izinsiz veya kaynak gösterilmeden kullanılması, reklam-haber ayrımının kaybolması ve profesyonel-kullanıcı ikiliği bağlamında ortaya çıkan etik sorunlar gelmektedir. Diğer yandan haber sitelerinin reklamlarla dolu olması, pop-upların açılması habere ulaşma noktasında kullanıcıyı yormakta, haber sitelerinin tasarımına ilişkin problemler ise çoğu zaman istenen enformasyona ulaşmayı zorlaştırmaktadır. İnternet haberciliği bağlamında ortaya çıkan tüm bu etik sorunlar pek çok haber sitesinde görülebilmektedir. Bu hususlar, haber sitelerinde kullanılabilirlik sorunlarını ortaya çıkarmaktadır. İnternet haber sitelerinin kullanılabilirliğinin göz izleme cihazı yardımıyla kullanıcı ekseninde ortaya konulduğu çalışmada 'İnternet haber sitelerinde kullanılabilirlik açısından nasıl sorunlar ortaya çıkmaktadır?', 'İnternet haber siteleri nasıl daha kullanışlı hale getirilebilir?' gibi sorulara yanıt aramaktadır. Bu bağlamda çalışmanın temel amacı internet haber sitelerinde ortaya çıkan kullanılabilirlik sorunlarını tespit etmek, sorunların ortadan kaldırılmasına ve internet haber sitelerinin daha kullanışlı hale getirilmesine yönelik öneriler sunmaktır.

\section{Alan Yazı}

\subsection{Internet Ortamında Haber}

Askeri amaçlarla ARPANET projesi çerçevesinde 1969 yılında dört bilgisayar arasında yapılan bağlantı ile internetin ilk şekli ortaya çıkmış, 1989 yılında ise Tim Bernard 'WWW' (World Wide Web) teknolojisini geliştirmiştir. Bu teknoloji ile internetin grafik ortamda sayfalar biçiminde üretilmesi sağlanmış ve bugünkü anlamda bildiğimiz internet doğmuştur (Toruk, 2008: 268-269). 1990'lı yıllarda sivilleşen ve yüzyılın sonuna doğru evlerde de kullanılmaya başlanan internet pek çok alanda büyük dönüşümler yaşanmasına neden olmuştur. Dreyfus'un ifade ettiği gibi internet yalnızca teknolojik bir yenilik değil aynı zamanda teknolojik yeniliğin bir tipidir (2016: 13). Bu çerçevede internet toplumsal alanın tümüne nüfuz ederek değişim ve dönüşüme neden olan yapısıyla yeni tip bir teknolojiye işaret etmektedir. Bu yeni teknolojinin köklü değişimlere neden olduğu alanların başında ise gazetecilik gelmektedir.

İnternet ortamında gazeteler ilk olarak 1995 yılında Amerika'da görünmeye başlamıştır. Bununla birlikte internet ortamında ortaya çıkan ilk gazete örneklerinin günümüz internet gazeteciliğinden oldukça farklı olduğu bilinmektedir. İnternet ortamında gazetelerin ortaya çıktığı ilk yıllardan günümüze internet gazetecilinin tarihi dört döneme ayrılmaktadır. İnternet gazeteciliğinin ilk dönemi daha çok basılı gazetenin birebir internet ortamına aktarılması şeklinde 
gerçekleşmektedir. İkinci dönemde ise özgün haber içeriği web sitesi için düzenlenmektedir. Üçüncü dönemde web sitesi için tasarlanmış ve teknolojik yöntemler kullanılarak biçimlendirilmiş özgün haber içerikleri görülmektedir. $\mathrm{Bu}$ dönemde haberin hikâye edilmesinde teknolojik araçlar kullanılmakta ve haber bu yolla zenginleştirilmektedir. Dördüncü dönem ise web günlüklerinin dolayısıyla yurttaş gazeteciliğinin görünür olmaya başladığı süreci ifade etmektedir (Tokgöz, 2013: 112-113). Bu çerçevede internet haberciliğindeki değişim ve dönüşümün teknolojik gelişmelerle doğrudan bağlantılı olduğu görülmektedir. Bu teknolojik gelişmelerin başında ise web 2.0 teknolojisi gelmektedir.

Web 2.0 teknolojisinin ortaya çıkışına paralel olarak internet ortamı etkileşimli, eş zamansız ve kullanıcıyı bireysel olarak kuşatan bir yapıya bürünmüştür. Web 2.0 teknolojisiyle etkileşimli hale gelen internet ortamı kullanıcının içerik üretmesine, üretilen içeriği paylaşabilmesine ve yorum yapabilmesine olanak tanımıştır. Kullanıcının internet ortamında etkileşime açık hale gelmesi internet haberciliğinde önemli kırılmaların yaşanmasına zemin hazırlamıştır. Tüm bu gelişmeler gerek haber medyasında gerekse gazetecilik mesleğinde kaçınılmaz bir değişime kapı aralamıştır. $\mathrm{Bu}$ değişim gazetecilerin kendi kimliklerini yeniden tanımlamalarını zorunlu hale getirmiştir (Cangöz, 2015: 261).

İnternet haber okuyucusu, üretilen bir haberi paylaşabilmekte, yorum yapabilmekte ve habere katkı sunabilmektedir. Diğer taraftan web 2.0 teknolojisi ve sonrasında ortaya çıkan tablet, akıllı telefon gibi taşınabilir teknolojik araçlar haber yapım ve yayın sürecini büyük oranda etkilerken sıradan kullanıcının gazeteci gibi hareket ettiği 'yurttaş gazeteciliği' olarak adlandırılan bir gazetecilik pratiğini ortaya çıkarmıştır. Dolayısıyla teknolojik gelişmeler sıradan kullanıcıyı haber yapım ve yayın süreçlerine dâhil etmiştir.

İnternet haberciliği bağlamında ortaya çıkan önemli gelişmelerden biri de haberi hikâye etme ve sunma biçimlerinde görülmektedir. Haber metninin yanı sıra fotoğraf, grafik-şekiller, sayılar, istatistiki bilgiler ile bu bilgilerin sunum biçimi önem kazanmış ve haber içeriği kadar sunum zenginliği de son derece önemli hale gelmiştir (Törenli, 2005: 174-175). İnternet ortamının çoklu ortam özelliği haberin ses, görüntü, video ve grafiklerle desteklenerek hikayeleştirilmesini olanaklı hale getirirken hipermedya özelliği ise internet ortamındaki haberin sayfa kısıtlaması olmaksızın sunulmasını sağlamaktadır. Hipermedya, köprü mantığını kullanarak linkler aracılığıyla habere bağlantı verilmesi ve böylece haberin daha geniş bir perspektifte ve çok yönlü olarak sunulmasını ifade etmektedir. Bu uygulamalar haber hikâyelerini daha zengin tarihi, siyasi ve kültürel çerçevede ele alan gazeteciliğin yeni bir formunu göstermektedir (Pavlik, 2013: 29).

Deuze, internet gazeteciliğini dört ana başlık altında sınıflandırmaktadır. İnternette ortaya çıan habercilik biçimlerinden ilki geleneksel medya kuruluşları tarafindan gerçekleştirilen ve editoryal kontrolün yüksek olduğu ana akım haber siteleridir. İkinci tür haber siteleri ise endeks ve kategori siteleri olarak adlandırılmakta ve haberin sunumu, haber sitelerine link verilmesi ile gerçekleşmektedir. Arama motorları bu kategoriye girmektedir. Üçüncüsü eleştiri ve yorum siteleridir. Dördüncü tür internet gazeteciliği ise paylaşım ve tartışma siteleridir (Aktaran: Geray ve Aydoğan, 2010). İnternet ortamında habercilik biçimlerine bağlı olarak ortaya çıkan bu farklılaşma haberin niteliğini de etkilemektedir.

Yeni iletişim teknolojilerinde yaşanan gelişmelerle haber dijital ortamda üretilen ve yine aynı ortamda tüketilen bir nitelik kazanırken yeni habercilik biçimlerinin ortaya çıkmasına da zemin hazırlamıştır. Bunlardan biri yukarıda değindiğimiz yurttaş veya vatandaş gazeteciliğidir. Bir diğeri ise akıllı telefonların günlük yaşamın ayrılmaz bir parçası haline gelmesinin bir sonucu olarak ortaya çıan ve genellikle anlık haber verme, canlı yayın ya da kriz dönemlerinde etkin olarak kullanılan mobil haberciliktir (Değirmencioğlu, 2016). Son zamanlarda sıklıkla üzerinde durulan ve verinin habercilikte etkin bir şekilde kullanılmasını amaçlayan veri gazeteciliği bir diğer gazetecilik biçimidir. Aslında bu gazetecilik türü tarihsel olarak görebileceğimiz fakat teknolojik gelişmelerle 
birlikte tekrardan gün yüzüne çıkan bir habercilik modeline işaret etmektedir. Veri gazeteciliğinde amaç verinin analiz edilerek anlamlı ve anlaşılır bir hale getirilmesi ve elde edilen kritik bilgilerin okuyucuya sunulmasıdır. Verinin anlaşılır bir şekilde okuyucuya sunulması noktasında ise veri görselleştirme yöntemlerinden yararlanılmaktadır. Veri görselleştirme yöntemleri yalnızca veri gazeteciliğinde değil birçok haberde etkin olarak kullanılmaktadır. Özellikle ücretsiz olarak kullanılabilecek pek çok veri görselleştirme aracı bunu kolaylaştırmaktadır. Haber sunumu açısından ortaya çıkan yeni gelişmelerden biri de infografik haber tasarımından yararlanılmasıdır.

Gazeteciliğin internet ortamına taşınması habercilik açısından pek çok olumlu gelişmeyi beraberinde getirmekle birlikte birçok etik sorun yaratmaktadır. $\mathrm{Bu}$ etik sorunların başında görüntüyle oynama, bilgi yanılsaması, sosyalleşme sitelerinin amacı dışında kullanılması, içeriğin izinsiz veya kaynak gösterilmeden kullanılması, reklam-haber ayrımının kaybolması ve profesyonelkullanıcı ikiliği bağlamında ortaya çıkan etik sorunlar gelmektedir (Geray ve Aydoğan, 2010). İnternet haberciliği bağlamında ortaya çıan tüm bu etik sorunlar pek çok haber sitesinde görülebilmektedir. Bununla birlikte haber sitelerinin reklamlarla dolu olması, pop-upların açılması habere ulaşma noktasında kullanıcıyı yormakta, haber sitelerinin tasarımı ise çoğu zaman istenen enformasyona ulaşmayı zorlaştırmaktadır.

\section{2.İnsan Bilgisayar Etkileşimi}

İnsan Bilgisayar Etkileşimi (İBE) kavramı; insan ve bilgisayar arasındaki etkileşimi, bu etkileşimin niteliğini tanımlama ve tasarlama düzleminde ortaya çıkmıştır (Myers, 1994). Sosyal ve davranışsal bilimler ile bilgi ve iletişim teknolojilerinin kesişim noktasında olan İnsan Bilgisayar Etkileşimi, insanlar tarafından teknolojik tabanlı sistemlerin kullanımına ve bu sistemlerin daha kullanılabilir hale getirilmesine odaklanmaktadır (Carrol, 2003). İnsan Bilgisayar Etkileşimi, sadece sağduyu ve şans değil yeri geldiğinde farklı disiplinlerin katkısı olan ciddi bir ön hazırlık sürecinin yanı sıra deney sürecini de içermektedir. Bu yönüyle İnsan Bilgisayar Etkileşimi, basit bir bilgisayar kullanma deneyiminin ötesinde bir birikim gerektirmektedir (Myers, 1994). Bu doğrultuda İnsan Bilgisayar Etkileşimi çalışmaları, bilgi ve iletişim teknolojilerinin insan odaklı üretimini temel almaktadır.

Etkileşime dayalı teknolojilerin tasarımı, geliştirilmesi, değerlendirilmesi ve uygulanması ile ilgilenen İnsan Bilgisayar Etkileşimi, sosyolojiden endüstriyel tasarıma, psikolojiden yazılım mühendisliğine kadar birçok farklı alanla yakından ilişkili olması açısından disiplinler arası bir niteliğe sahiptir. Bu yönüyle İnsan Bilgisayar Etkileşimi, insan ihtiyaçlarını referans alarak insanın teknolojiye değil, teknolojinin insana uymasını amaçlayan teorik ve pratik çalışmaları tanımlamaktadır (Çağıltay, 2011: 1, 5). Dolaysıyla İnsan Bilgisayar Etkileşimi çalışmaları, insan ve bilgisayar arasındaki etkileşimin boyutlarını tanımlama çerçevesinde teknolojiye daha kullanılabilir nitelikler kazandırarak etkileşimin sağlıklı hale getirilmesini hedeflemektedir.

\subsection{Kullanılabilirlik}

İnsan Bilgisayar Etkileşimi, kullanılan araçlarla belirli işlerin gerçekleştirilme pratiklerinin değerlendirilmesi ve bu değerlendirmeler doğrultusunda ilgili sistemlerin geliştirilmesi sürecinde önem taşıyan dört temel bileşene sahiptir. Bunlar; kullanıcı, görev (task), araç/arayüz (tool) ve bağlam (context)'dır (Acartürk ve Çağıltay, 2006). Bu bileşenler, 'kullanılabilirlik' (usability) kavramı ile yakından ilişkilidir.

Kullanılabilirlik kavramına, "kullanıcı dostu”, "kullanım kolaylığı”, "öğrenme kolaylığı”, "şeffaflık", ve "sezgisel kullanım" gibi anlamlar yüklenmektedir. Ancak kullanılabilirlik kavramına yüklenen bu anlamlar belirsiz olmakla birlikte kişiden kişiye değişen bir niteliğe sahiptir. Kullanılabilirlik kavramına ilişkin daha net, göreceli olmayan bir tanım için ürün özellikleri ile arayüz özelliklerini temel alan yaklaşımlar söz konusudur. Ancak bu yaklaşımlar İnsan Bilgisayar Etkileşimi açısından kullanılabilirlik tanımının geçerliliği konusunda soru işaretlerini ortadan 
kaldırmamıştır. Kullanılabilirlik kavramına ilişkin farklı tanımlar yapılsa da açıklayıcı, net, tasarım için kullanım potansiyeli taşıyan ve bu yönüyle herkes için geçerli olabilecek bir tanım Uluslararası Standartlar Enstitüsü (International Standarts Organization 'ISO') tarafından yapılmıştır. Buna göre kullanılabilirlik, "belirli bir kullanıcı grubunun, belirli görevleri, belirli bir bağlamda, etkili, verimli ve memnuniyet ile yerine getirmeleri" biçiminde tanımlanmaktadır (Çağıltay, 2011: 85-91). Dolayısıyla kullanılabilirlik kavramı basit ve tek yönlü bir anlama sahip olmaktan ziyade kullanıcıların herhangi bir ürün ya da sistem ile etkileşimine etki eden tüm unsurları kapsayan bir kombinasyona işaret etmektedir (Nielsen, 1993: 26).

İnsan Bilgisayar Etkileşimi çerçevesinde kullanılabilirlik, belirlenen kriterler üzerinden belirli görevlerin kullanıcılar tarafından gerekli destek sağlanarak uygun koşullarda etkin ve kolay bir biçimde gerçekleştirilebilmesini ifade etmektedir. Kullanıcılara, yapılan iş ve koşullara göre değişen kullanılabilirlik çalışmalarında etkileşim, etkileşime dayalı arayüzler, kullanılabilirlik testleri, kullanıcı psikolojisi, sosyoteknolojik sistem tasarımı ve yeni teknolojilere karşı direnç incelenmektedir. Bu incelemeler ve ölçümler çerçevesinde ortaya çıkan kullanılabilirlik derecesi kullanıcıların verilen görevleri yerine getirirken gösterdikleri verimlilik (efficiency), etkililik (effectivity) ve memnuniyetleri (satisfaction) üzerinden belirlenmektedir (Acartürk ve Çağıltay, 2006). Belirlenen hedefler doğrultusunda kullanım kolaylığı yaratan arayüzlerin geliştirilmesi ve geliştirilmiş arayüzlere ilişkin testlerin yapılması amacıyla gerçekleştirilen yaklaşımlar genellikle "kullanılabilirlik testleri - usability tests" biçiminde tanımlanmaktadır (Çağıltay, 2011: 100). Kullanılabilirlik, farklı kullanıcıların belirli görevleri yapabilmesine odaklı kullanıcı testleri üzerinden ölçülmektedir (Nielsen, 1993: 27).

Bir ürüne ilişkin kullanılabilirlik testi, kullanıcıların ürün deneyimlerinin ölçümüne dayanmaktadır. Anlamlı sonuçlara ulaşmak için sistemin tüm fonksiyonel yapısı ile kullanıcıların bilişsel kapasitesinin dikkate alınması gerekmektedir (Dix vd., 2004: 237). Kullanılabilirlik testleri, incelenen yapının kalitesini, kullanım kolaylığını, öğrenme kolaylığını ve bu çerçevede kullanıcı memnuniyetini tüm yönleri ile ortaya çıkarmayı hedeflemektedir. Bu bağlamda kullanılabilirliğin ölçümü ve elde edilen sonuçlar; tasarımın işlevselliğini, dolayısıyla İnsan Bilgisayar Etkileşimi'nin boyutlarını ortaya koymaktadır. Elde edilen bulgular ise kullanılabilirlik üzerine tespitler ve bu tespitler üzerinden kullanılabilirliğin daha iyi düzeylere çekilmesi hedefine yönelik önerileri ortaya çıkarmaktadır.

Nielsen (1993), bir kullanılabilirlik çalışmasında katılımcı sayısı ile bir testin başarı oranı arasındaki ilişkiyi 'kullanılabilirlik problemleri ve kullanıcı sayısı ilişkisi' başlığı altında ele almış ve 5 katılımcı ile $\% 75$ oranında başarı elde edilebileceğini belirtmiştir. Bununla birlikte Nielsen (2000), test stiline bağlı olarak bir çalışmada 3-5 kişilik homojen katılımcı grubu ile yapılan çalışmanın dahi yeterli olabileceğini vurgulamıştır. Dolayısıyla örneğin 5 gibi optimum bir sayı ile yapılan kullanılabilirlik testi, bütçe veya zaman kısıtlamalarını aşmayı sağlarken tasarım üzerindeki hata payının azaltılmasını temel alan yinelemeli uygulamaların önünü açmaktadır (Nielsen ve Landuer, 1993).

\subsection{Göz İzleme}

Göz izleme, kullanıcıların göz hareketlerinin tespitine yönelik belirli uyaranlar üzerinde kullanıcıların dikkat kalıplarını ortaya koymaktadır. Bu anlamda göz izleme süreçleri kullanıcıların nereye ne kadar süre baktığı konusunda nesnel ve nicel kanıtlar sağlamaktadır (Duchowskia, 2002).

Uzun yıllardır var olan göz izleme; yazılım ve donanıma ilişkin gelişmelerle birlikte kullanılabilirlik ölçümlerinde daha uygulanabilir bir yaklaşım olma özelliği kazanmıştır. Günümüzde özellikle web sitesi tasarımlarında dikkat çekici unsurların ve sorunlu alanların tespiti gibi bilgilerin elde edilmesinde göz izleme önemli işlevlere sahiptir (Dix vd., 2004: 354). İnsan Bilgisayar Etkileşimi çerçevesinde 'bakış'ın ayrıntılı bilgisine ulaşma ve yorumlama çalışmalarını ifade eden göz izleme, karmaşık bir metdololoji olarak görülmektedir. Farklı disiplinlerde farklı amaçlarla 
kullanılabilen göz izleme, teknolojik gelişmelere bağlı olarak yazılım ve donanım çözümleriyle geliştirilmiştir (Brône ve Oben, 2018: 6).

$\mathrm{Bu}$ çalışmanın göz izleme sürecinde RED250 bilgisayarı ve göz izleme yazılımlarından ekran tabanlı göz izleme modülü kullanılmıştır. 22 inçlik LCD test monitörünün alt kısmına yerleştirilmiş olan göz izleme aparatı ile test monitörü üzerinde katılımcıların belirlenen haber sitelerini okuma sürecindeki göz hareketleri kayıt altına alınmıştır.

\section{Yöntem}

\section{1. Çalışma Grubu}

Çalışmanın gerçekleştirilebilmesi için Atatürk Üniversitesi Sosyal Bilimler Enstitüsü Gazetecilik Anabilim Dalı öğrencilerine danışmanları aracılığıyla ulaşılmış, bu öğrenciler arasından 25-30 yaş aralığında, 5'i kadın, 5'i erkek olmak üzere ders ve tez aşamasında bulunan 10 öğrenci gönüllük esasına dayalı olarak belirlenmiştir. Katılımcılar yaş ve eğitim durumları bakımından benzer özelliklere sahiptir. Bu noktadan hareketle katılımcıların benzer algı düzeyine sahip oldukları varsayılmıştır.

\subsection{Görevler}

Seçilen haber siteleri üzerinden katılımcilara verilecek görevlerin belirlenmesine dönük bir ön çalışma yapılmıştır. Bu ön çalışmada Atatürk Üniversitesi Sosyal Bilimler Enstitüsü Gazetecilik Anabilim Dalı'nda Yüksek Lisans öğrenimi gören 20 öğrenciye haber sitelerine hangi amaçlarla girdikleri, haber sitelerinde en çok neler yaptıkları ve bir haber sitesinde en çok baktıkları alanlar sorulmuştur. Elde edilen veriler 1şı̆̆ında çalışmanın amacına uygun görevler belirleniştir. $\mathrm{Bu}$ kapsamda 'haber açma' ve 'her komut sonrası ana sayfaya dönme' şeklindeki temel görevlerin dışında kullanıcıların haber sitelerinde en çok gerçekleştirdikleri eylemler arasından 'son dakika haberlerine ulaşma' ve 'haber arşivini açma', erişilebilirlik bağlamında önemli görüldüğünden; 'haberi paylaşma' ve 'habere yorum yapma' ise etkileşim açsından önemli görüldüğünden görev kategorilerine dahil edilmiştir.

\subsection{Haber Sitelerinin Seçimi}

Çalışma kapsamında kullanılabilirlik testine tabi tutulacak olan haber sitelerinin seçiminde amaçlı örneklem tekniğinden yararlanılmıştır. Amaçlı örneklem, önceden tanımlanarak belirlenmiş amaç doğrultusunda evrenin genelini temsil edebilecek ve bu yönüyle araştırmanın amaçlarına en uygun verileri sağlayabilecek nitelikteki birimlerin incelemeye tabi tutulmasını temel almaktadır (Erdoğan, 2012: 210). Bu doğrultuda dünyanın en yaygın web trafik ve analiz ölçümü yapan kuruluşlarından olan Alexa ve Similarweb üzerinden aylık toplam ziyaret edilme sayısı, sitede günlük zaman geçirme ve ziyaretçi başına günlük sayfa görüntüleme sayısı gibi kriterler temel alınmıştır. Buna göre Ağustos-Eylül 2019 verilerine göre en çok tıklanan 10 haber sitesi arasından, belirlenen görev kategorilerine uygun, bu yönüyle benzer özellikler gösteren ensonhaber.com, haber7.com ve hurriyet.com.tr olmak üzere üç haber sitesi seçilmiştir.

\subsection{Veri Toplama Araçları}

İnternet haber sitelerinin kullanılabilirliğine odaklanan çalışmada verilerin toplanması noktasında farklı araçlar kullanılmıştır. Bu araçlar; ön mülakat formu, kişisel bilgi formu, göz takip cihazı ve deney sonrası mülakattan oluşmaktadır.

\subsection{Pilot Çalışma ve Deney Süreci}

Çalışmanın göz izlemeye dayalı ayağından önce haber siteleri üzerinden katılımcılara verilecek görevlerin belirlenmesi için katılımcıların haber sitelerine hangi amaçlarla girdikleri, haber sitelerinde en çok neler yaptıkları ve bir haber sitesinde en çok baktıkları alanların belirlenmesinde açık uçlu sorular içeren bir ön çalışma yapılmıştır. Bu ön çalışmadaki sorular, lisansüstü öğrenim 
görmekte olan 20 öğrenciye yöneltilmiştir. Çalışmanın göz izleme cihazı kullanılan aşamasına geçilmeden önce 2 kadın ve 2 erkek katılımcı ile pilot bir çalışma yapılııştır. Bu süreçte deneyin süresi, haber sitelerinin peş peşe gösterilip gösterilmeyeceği ve bu sürecin nasıl işleyeceğine ilişkin bir planlama yapılmıştır.

10 katılımcı ile gerçekleşecek olan deneyden önce katılımcıların demografik bilgileri, haberleri takip ettikleri mecra, haber okuma sıklığı ve en çok haber okunulan haber sitesi, kişisel bilgi formu doldurtularak kayıt altına alınmış̦ır. Çalışmada yer alan 10 katılımoının belirlenen haber sitelerini kullanmıyor olmalarına özellikle dikkat edilmiştir.

Çalışmanın göz izlemeye dayalı ayağı ise Atatürk Üniversitesi Açıöğretim Fakültesi İnsan Bilgisayar Etkileşim Laboratuvarı'nda SMI (SensoMotoric Instruments) RED250 göz izleme cihazı ile bileşenleri kullanılarak gerçekleştirilmiştir. Deneyin hazırlık sürecinde göz izleme cihazına ilişkin detaylı ön ayarların yapılması amacıyla SMI iViewRED göz izleme cihazı kontrol yazılımı; deneyin uygulanmasında ve deney sürecinin yönetiminde SMI Experiment Center 3.7; kayıt altına alınan verilerin analizinde ve analizlere ilişkin grafik, haritalar ve diğer görselleştirmelerin alınmasında ise SMI BeGaze 3.7 yazılımı kullanılmıştır.

Deney sonrası, katılımcıların görevleri gerçekleștirdikleri internet haber sitelerinin kullanılabilirliğine ilişkin görüşleri mülakat formu ile kayıt altına alınmıştır. Bu mülakat formunda katılımcılara; "Kullanırken en çok zorlandığınız haber sitesi hangisidir? Neden?", "Haber sitelerinde sizi en çok rahatsız eden unsurlar nelerdir?", "Daha çok hangi haber sitesinin kullanışlı olduğunu düşünüyorsunuz? Neden?” şeklinde sorular yöneltilmiştir.

Çalışma kapsamında ön mülakat, göz izleme cihazı (eye tracking), kişisel bilgi formu ve internet haber sitelerine yönelik mülakat üzerinden elde edilen veriler analiz edilmiştir. Göz izleme cihazıyla örneklem grubu olarak seçilen 10 katılımcının belirlenen 3 haber sitesinde 6 temel görevi gerçekleştirip gerçekleştiremediği ile bu görevlerin gerçekleştirilme süresi ölçülmüştür. Diğer yandan katılımcıların örnek olarak seçilen her bir haber sitesindeki ilk bakış noktalarının tespitinde kullanılan Bee Swarm analizi ile katılımcıların bakış konumlarına ilişkin veri sağlanmıştır. Göz tarama yolu (Scan Path) ve tıklama noktaları da söz konusu görevlerin yapılabilmesi açısından göz izleme cihazı ile tespit edilmiştir. Katılımcıların haber okuma sıklığı ve haber okuduğu mecra ile internet haber sitelerinde verilen görevlerin yapılabilmesi ve süresi arasında mantıklı bir ilişki olup olmadığına da bakılmıştır. Bu çerçevede görev tamamlama ve süresi temel alınarak hangi haber sitelerinin kullanılabilirlik açısından daha uygun olduğu, hem tüm katılımcılar hem de cinsiyet değişkeni bağlamında ortalama süre üzerinden tespit edilmiştir. Bu doğrultuda çalışma sonunda elde edilen veriler karşılaştırılarak betimsel analiz yöntemi ile analiz edilmiştir.

\section{Analiz}

Göz izleme cihazı kullanılarak gerçekleştirilen deneyde katılımcıların komutla verilen görevleri tamamlamalarına ilişkin ölçümün sonuçları Tablo 1'de gösterilmiştir. Buna göre 10 katılımcıdan 4'ü tüm görevleri başarı ile tamamlamıştır. Diğer 6 katılımcı ise farklı haber sitelerine yönelik görevlerden bazılarını tamamlayamamıştır.

Tablo 1'deki veriler, görevlerin tamamlanması açısından ele alındığında son dakika haberlerine ulaşma, haber açma ve her komut sonrası ana sayfaya dönme görevlerinin tüm katılımcılar tarafından eksiksiz yerine getirildiği görülmektedir. Ancak paylaşım yapma görevi $1 \mathrm{kez}$, yorum yapma görevi $5 \mathrm{kez}$ arşive ulaşma görevi ise $7 \mathrm{kez}$ gerçekleştirilememiştir. Buna göre katılımcıların son dakika haberlerine ulaşma, haber açma, her komut sonrası ana sayfaya dönmede başarı oranı $\% 100$ olarak tespit edilirken arşive ulaşmada başarı oranı $\% 76,66$, paylaşım yapmada $\% 96,66$, yorum yapmada ise \%83,66 olarak tespit edilmiştir. Bu veriler haber sitesi bazında ele alındığında ensonhaber.com'da 3 , hurriyet.com.tr'de 2 katılımcının yorum yapamadığı; haber7.com'da 1 katılımcının paylaşım yapamadığı; ensonhaber.com'da 2, hurriyet.com.tr'de 2, 
haber7.com'da ise 3 katılımcının arşive ulaşma görevini tamamlayamadı̆̆ tespit edilmiştir. Dolayısıyla bu verilere göre arşive ulaşma, yorum yapma ve paylaşım yapma görevlerinin gerçekleştirilme oranının düşük oluşu, haber sitelerinin bu açılardan kullanılabilirlik sorununa işaret etmektedir.

Tablo 1: Katılımcıların Görev Tamamlama Tablosu

\begin{tabular}{|c|c|c|c|c|c|c|c|}
\hline & Siteler & $\begin{array}{l}\text { Arşive } \\
\text { Ulaşma }\end{array}$ & $\begin{array}{c}\text { Son Dakika } \\
\text { Haberlerine } \\
\text { Ulaşma }\end{array}$ & $\begin{array}{l}\text { Haber } \\
\text { Açma }\end{array}$ & $\begin{array}{c}\text { Paylaşım } \\
\text { Yapma }\end{array}$ & $\begin{array}{c}\text { Her Komut } \\
\text { Sonrası Ana } \\
\text { Sayfaya } \\
\text { Dönme }\end{array}$ & $\begin{array}{l}\text { Yorum } \\
\text { Yapma }\end{array}$ \\
\hline \multirow{3}{*}{$K 1$} & Ensonhaber.com & $\checkmark$ & $\checkmark$ & $\checkmark$ & $\checkmark$ & $\checkmark$ & $\checkmark$ \\
\hline & Hurriyet.com.tr & $\checkmark$ & $\checkmark$ & $\checkmark$ & $\checkmark$ & $\checkmark$ & $x$ \\
\hline & Haber7.com & $\checkmark$ & $\checkmark$ & $\checkmark$ & $\checkmark$ & $\checkmark$ & $\checkmark$ \\
\hline \multirow{3}{*}{$K 2$} & Ensonhaber.com & $\checkmark$ & $\checkmark$ & $\checkmark$ & $\checkmark$ & $\checkmark$ & $x$ \\
\hline & Hurriyet.com.tr & $\checkmark$ & $\checkmark$ & $\checkmark$ & $\checkmark$ & $\checkmark$ & $\checkmark$ \\
\hline & Haber7.com & $\checkmark$ & $\checkmark$ & $\checkmark$ & $\checkmark$ & $\checkmark$ & $\checkmark$ \\
\hline \multirow{3}{*}{$K 3$} & Ensonhaber.com & $\checkmark$ & $\checkmark$ & $\checkmark$ & $\checkmark$ & $\checkmark$ & $\checkmark$ \\
\hline & Hurriyet.com.tr & $\checkmark$ & $\checkmark$ & $\checkmark$ & $\checkmark$ & $\checkmark$ & $\checkmark$ \\
\hline & Haber7.com & $\checkmark$ & $\checkmark$ & $\checkmark$ & $\checkmark$ & $\checkmark$ & $\checkmark$ \\
\hline \multirow{3}{*}{$K 4$} & Ensonhaber.com & $\checkmark$ & $\checkmark$ & $\checkmark$ & $\checkmark$ & $\checkmark$ & $\checkmark$ \\
\hline & Hurriyet.com.tr & $\checkmark$ & $\checkmark$ & $\checkmark$ & $\checkmark$ & $\checkmark$ & $\checkmark$ \\
\hline & Haber7.com & $\checkmark$ & $\checkmark$ & $\checkmark$ & $\checkmark$ & $\checkmark$ & $\checkmark$ \\
\hline \multirow{3}{*}{ K5 } & Ensonhaber.com & $x$ & $\checkmark$ & $\checkmark$ & $\checkmark$ & $\checkmark$ & $\checkmark$ \\
\hline & Hurriyet.com.tr & $x$ & $\checkmark$ & $\checkmark$ & $\checkmark$ & $\checkmark$ & $\checkmark$ \\
\hline & Haber7.com & $x$ & $\checkmark$ & $\checkmark$ & $x$ & $\checkmark$ & $\checkmark$ \\
\hline \multirow{3}{*}{$K 6$} & Ensonhaber.com & $x$ & $\checkmark$ & $\checkmark$ & $\checkmark$ & $\checkmark$ & $\checkmark$ \\
\hline & Hurriyet.com.tr & $\checkmark$ & $\checkmark$ & $\checkmark$ & $\checkmark$ & $\checkmark$ & $\checkmark$ \\
\hline & Haber7.com & $x$ & $\checkmark$ & $\checkmark$ & $\checkmark$ & $\checkmark$ & $\checkmark$ \\
\hline \multirow{3}{*}{ K7 } & Ensonhaber.com & $\checkmark$ & $\checkmark$ & $\checkmark$ & $\checkmark$ & $\checkmark$ & $\checkmark$ \\
\hline & Hurriyet.com.tr & $\checkmark$ & $\checkmark$ & $\checkmark$ & $\checkmark$ & $\checkmark$ & $\checkmark$ \\
\hline & Haber7.com & $x$ & $\checkmark$ & $\checkmark$ & $\checkmark$ & $\checkmark$ & $\checkmark$ \\
\hline \multirow{3}{*}{$K 8$} & Ensonhaber.com & $\checkmark$ & $\checkmark$ & $\checkmark$ & $\checkmark$ & $\checkmark$ & $x$ \\
\hline & Hurriyet.com.tr & $x$ & $\checkmark$ & $\checkmark$ & $\checkmark$ & $\checkmark$ & $\checkmark$ \\
\hline & Haber7.com & $\checkmark$ & $\checkmark$ & $\checkmark$ & $\checkmark$ & $\checkmark$ & $\checkmark$ \\
\hline \multirow{3}{*}{ K9 } & Ensonhaber.com & $\checkmark$ & $\checkmark$ & $\checkmark$ & $\checkmark$ & $\checkmark$ & $x$ \\
\hline & Hurriyet.com.tr & $\checkmark$ & $\checkmark$ & $\checkmark$ & $\checkmark$ & $\checkmark$ & $x$ \\
\hline & Haber7.com & $\checkmark$ & $\checkmark$ & $\checkmark$ & $\checkmark$ & $\checkmark$ & $\checkmark$ \\
\hline \multirow{4}{*}{ K10 } & Ensonhaber.com & $\checkmark$ & $\checkmark$ & $\checkmark$ & $\checkmark$ & $\checkmark$ & $\checkmark$ \\
\hline & Hurriyet.com.tr & $\checkmark$ & $\checkmark$ & $\checkmark$ & $\checkmark$ & $\checkmark$ & $\checkmark$ \\
\hline & Haber7.com & $\checkmark$ & $\checkmark$ & $\checkmark$ & $\checkmark$ & $\checkmark$ & $\checkmark$ \\
\hline & Başarı Oranı & $\% 76,66$ & $\% 100$ & $\% 100$ & $\% 96,66$ & $\% 100$ & $\% 83,33$ \\
\hline
\end{tabular}

Çalışma kapsamında örneklem olarak seçilen 10 katılımcının haber okuma sıklığı, haber okuduğu mecra ve görev tamamlama süreleri Tablo 2'de verilmiştir. Bu verilere göre katılımcıların tamamı her gün haber takip etmektedir. Katılımcılardan 8'i gün içinde sık aralıklarla haber takip ederken 2'si ise gün içinde nadiren haberlere bakmaktadır. Katılımcıların haber takip ettikleri mecralar ele alındığında; 7 katılımcının Twitter'dan, 5 katılımcının Instagram'dan, 2 katılımcının haber sitelerinden, 1 katılımcının ise Facebook'tan gündemi ve haberleri takip ettiği sonucuna ulaşılmıştır. Dolayısıyla katılımcıların haberleri genellikle internet haber sitelerinden değil sosyal medyadan takip ettiği görülmektedir. Tablo 1 ve Tablo 2'deki veriler birlikte ele alındığında özellikle diğer görevlerin dışında kalan arşive ulaşma, yorum yapma ve paylaşım yapma görevlerindeki başarı 
oranının düşük olması katılımcıların haber sitelerine çok aşina olmaması ile ilişkilendirilebilir. Çünkü katılımcıların büyük bir kısmı, haber takibini haber sitelerinden değil sosyal medyadan yapmaktadir.

Katılımcıların görev tamamlama süresi dikkate alındığında, bir katılımcı hariç (K2) tüm katılımc1ların görevlerini en uzun sürede tamamladığı haber sitesinin hurriyet.com.tr olduğu görülmüștür. Ayrıca hurriyet.com.tr'de hiçbir katılımcı görevleri diğer haber sitelerine göre erken tamamlayamamıştır. Haber7.com 2 katılımcının, ensonhaber.com ise 7 katılımcının tüm görevleri en erken yerine getirdiği site olarak dikkat çekmektedir. Dolayısıyla hurriyet.com.tr katılımcıların en çok ensonhaber.com ise en az zaman harcayarak görevleri yerine getirdiği haber siteleri olmuştur. Görev tamamlama süreleri cinsiyet değișkeni bağlamında ele alındığında erkeklerin toplam görev tamamlama süresinin katılımcı ortalaması 198 saniye, kadınların görev tamamlama süresinin katılımcı ortalaması ise 217 saniyedir.

Tablo 2: Katılımcı ve Haber Sitesi Bazında Görev Tamamlama Süreleri

\begin{tabular}{|c|c|c|c|c|c|c|}
\hline & & Haber Siteleri & $\begin{array}{c}\text { Görev } \\
\text { Tamamlama } \\
\text { Süresi }\end{array}$ & $\begin{array}{c}\text { Toplam } \\
\text { Görev } \\
\text { Tamamlama } \\
\text { Süresi } \\
\end{array}$ & $\begin{array}{c}\text { Haber } \\
\text { Okuma } \\
\text { Sıklığı }\end{array}$ & $\begin{array}{c}\text { Haber } \\
\text { Okuduğu } \\
\text { Mecra }\end{array}$ \\
\hline \multirow{15}{*}{$\frac{y}{x}$} & \multirow{3}{*}{$K 1$} & Ensonhaber.com & 69 & \multirow{3}{*}{267} & \multirow{3}{*}{$\begin{array}{c}\text { Her Gün } \\
\text { (Nadir) }\end{array}$} & \multirow{3}{*}{ Twitter } \\
\hline & & Hurriyet.com.tr & 116 & & & \\
\hline & & Haber7.com & 82 & & & \\
\hline & \multirow{3}{*}{$K 2$} & Ensonhaber.com & 154 & \multirow{3}{*}{278} & \multirow{3}{*}{$\begin{array}{l}\text { Her Gün } \\
\text { (S1k) }\end{array}$} & \multirow{3}{*}{ Twitter } \\
\hline & & Hurriyet.com.tr & 72 & & & \\
\hline & & Haber7.com & 52 & & & \\
\hline & \multirow{3}{*}{$K 3$} & Ensonhaber.com & 70 & \multirow{3}{*}{247} & \multirow{3}{*}{$\begin{array}{c}\text { Her Gün } \\
\text { (S1k) }\end{array}$} & \multirow{3}{*}{$\begin{array}{l}\text { Twitter, } \\
\text { Instagram }\end{array}$} \\
\hline & & Hurriyet.com.tr & 114 & & & \\
\hline & & Haber7.com & 63 & & & \\
\hline & \multirow{3}{*}{$K 4$} & Ensonhaber.com & 45 & \multirow{3}{*}{198} & \multirow{3}{*}{$\begin{array}{l}\text { Her Gün } \\
\text { (Nadir) }\end{array}$} & \multirow{3}{*}{$\begin{array}{l}\text { Facebook, } \\
\text { Instagram }\end{array}$} \\
\hline & & Hurriyet.com.tr & 85 & & & \\
\hline & & Haber7.com & 68 & & & \\
\hline & \multirow{3}{*}{$K 5$} & Ensonhaber.com & 50 & \multirow{3}{*}{211} & \multirow{3}{*}{$\begin{array}{l}\text { Her Gün } \\
\quad(\mathrm{S} 1 \mathrm{k})\end{array}$} & \multirow{3}{*}{$\begin{array}{c}\text { Haber site } \\
\text { Twitter }\end{array}$} \\
\hline & & Hurriyet.com.tr & 98 & & & \\
\hline & & Haber7.com & 63 & & & \\
\hline \multirow{15}{*}{ 萦 } & \multirow{3}{*}{$K 6$} & Ensonhaber.com & 76 & \multirow{3}{*}{269} & \multirow{3}{*}{$\begin{array}{l}\text { Her Gün } \\
(\mathrm{S} 1 \mathrm{k})\end{array}$} & \multirow{3}{*}{ Instagram } \\
\hline & & Hurriyet.com.tr & 106 & & & \\
\hline & & Haber7.com & 87 & & & \\
\hline & \multirow{3}{*}{$K 7$} & Ensonhaber.com & 44 & \multirow{3}{*}{218} & \multirow{3}{*}{$\begin{array}{c}\text { Her Gün } \\
\text { (Sik) }\end{array}$} & \multirow{3}{*}{ Haber Site } \\
\hline & & Hurriyet.com.tr & 100 & & & \\
\hline & & Haber7.com & 74 & & & \\
\hline & & Ensonhaber.com & 59 & & & \\
\hline & $K 8$ & Hurriyet.com.tr & 77 & 193 & Her Gün & Twitter, \\
\hline & & Haber7.com & 57 & & & \\
\hline & & Ensonhaber.com & 50 & & & \\
\hline & $K 9$ & Hurriyet.com.tr & 95 & 218 & Her Gün & Twitter, \\
\hline & & Haber7.com & 73 & & & \\
\hline & & Ensonhaber.com & 55 & & & \\
\hline & $K 10$ & Hurriyet.com.tr & 74 & 188 & Her Gun & Twitter \\
\hline & & Haber7.com & 59 & & & \\
\hline
\end{tabular}

Çalışma kapsamında katılımcıların verilen görevleri üç haber sitesinde saniye bazında kayıt altına alınan ortalama görev tamamlama süreleri Tablo 3'de gösterilmiştir. Buna göre katılımcıların her bir görev için ortalama harcadı ̆̆ zaman; haber açmada 4,80; son dakika haberlerine ulaşmada 5,43; paylaşım yapmada 6,97; arşive ulaşmada 25,43; yorum yapmada ise 33,60 olarak tespit edilmiştir. Dolayısıyla katılımcıların en çok zorlandığı ve görevi yaparken zaman kaybettiği iki görev kategorisi yorum yapma ve arşive ulaşma olarak ortaya çıkmıştır. 
Tablo 3: Görev Bazında ve Toplamda Görev Tamamlama Süre Ortalamas1

\begin{tabular}{cccccc}
$\begin{array}{c}\text { Arşive } \\
\text { Ulaşma }\end{array}$ & $\begin{array}{c}\text { Son Dakika Habere } \\
\text { Ulaşma }\end{array}$ & $\begin{array}{c}\text { Haber } \\
\text { Açma }\end{array}$ & $\begin{array}{c}\text { Paylaşım } \\
\text { Yapma }\end{array}$ & $\begin{array}{c}\text { Yorum } \\
\text { Yapma }\end{array}$ & TOPLAM \\
\hline $\mathbf{2 5 , 4 3}$ & 5,43 & 4,80 & 6,97 & 33,60 & 76,23 \\
\hline
\end{tabular}

Haber sitesi ekseninde katılımcıların toplamda ve cinsiyet değişkeni bağlamında görev tamamlama süresine ilişkin bilgiler Şekil 1'de verilmiştir. Şekil incelendiğinde ensonhaber.com'da kadınlar tüm görevleri ortalama 56.8, erkekler ise 77.6 saniyede tamamlamıştır. Bir diğer haber sitesi olan hurriyet.com.tr'de erkekler tüm görevleri ortalama 97, kadınlar 90.4 saniyede tamamlamıştır. Üçüncü haber sitesi olan haber7.com'da ise erkeklerin görev tamamlama süresi ortalama 65.6, kadınların ise 70 saniyedir. Toplam ortalama görev tamamlama süreleri dikkate alındığında ensonhaber.com 67.2, haber7.com 67.8, hurriyet.com.tr ise 93.7 saniye olarak tespit edilmiştir. $\mathrm{Bu}$ rakamlara göre verilen görevlerin en kısa sürede tamamlanabildiği haber sitesi ensonhaber.com'dur. ensonhaber.com ile haber7.com arasında ortalama görev tamamlanma süresi açısından çok az bir fark varken görevlerin yerine getirilmesinde en çok zaman kaybı yaşanan sitenin toplamda da, cinsiyet değişkeni bağlamında da hurriyet.com.tr olduğu görülmüştür.

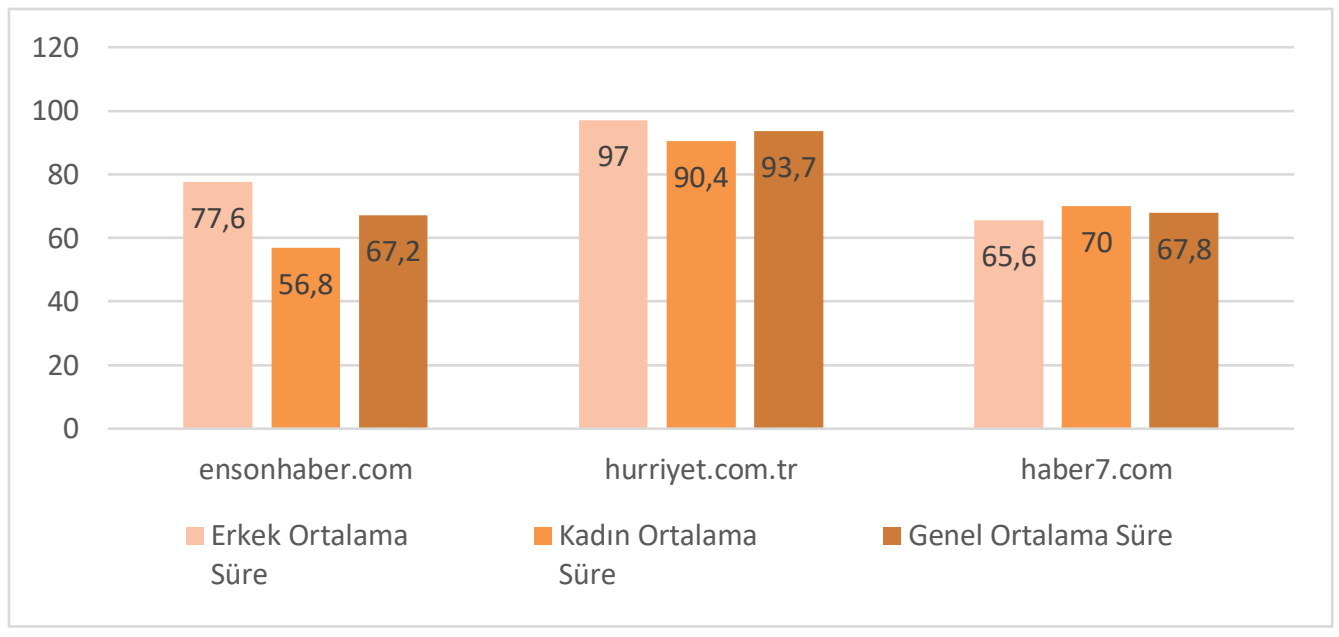

Şekil 1: Toplamda ve Cinsiyet Değişkeni Bağlamında Katılımcıların Görev Tamamlama Süresi

Bee swarm analizi çerçevesinde, seçilen haber sitelerinde katılımcıların ilk baktıkları nokta renkli çemberler ile gösterilmiştir. Şekil 2'de verilen ilk bakış noktası verilerine göre hurriyet.com.tr'de katılımcıların bazıları 'son dakika' yazısına baksa da çoğunluğu üst orta bölüme bakmıştır. hurriyet.com.tr' de tam bu bölüme banner reklamın yerleştirildiği, ayrıca bu haber sitesinin sağ ve sol boşluğunun da reklamla doldurulduğu görülmektedir. Dolayısıyla haber sitesindeki konumu ve boyutu itibariyle reklam, katılımcıların büyük bir kısmının dikkatini çekmiş ve ilk bakılan nokta olmuştur. Göz tarama yolunu ortaya koyan Scan path verileri ise hurriyet.com.tr'de kullanıcıların siteyi ve haberleri genel olarak soldan sağa, yukarıdan aşağıya taradıklarını göstermektedir. Bununla birlikte sağda, solda ve üst bölümde sabit ve hareketli reklamlar ile sağ alt köşede çıkan pop-up'ın kullanıcıların özellikle görevleri gerçekleştirirken göz tarama yolunu değiştirdiği görülmüştür. Dolayısıyla kullanıcıların göz hareketlerinde reklam ve pop-up kısmına doğru sıçramalar olmuştur. Kullanıcının dikkatini çeken bu hareketlilik gözün haber metinleri ve görsellerden kaymasına neden olurken pop-up'ın kapatılması gerekliliği tıklama noktalarını da değiştirmiştir. 


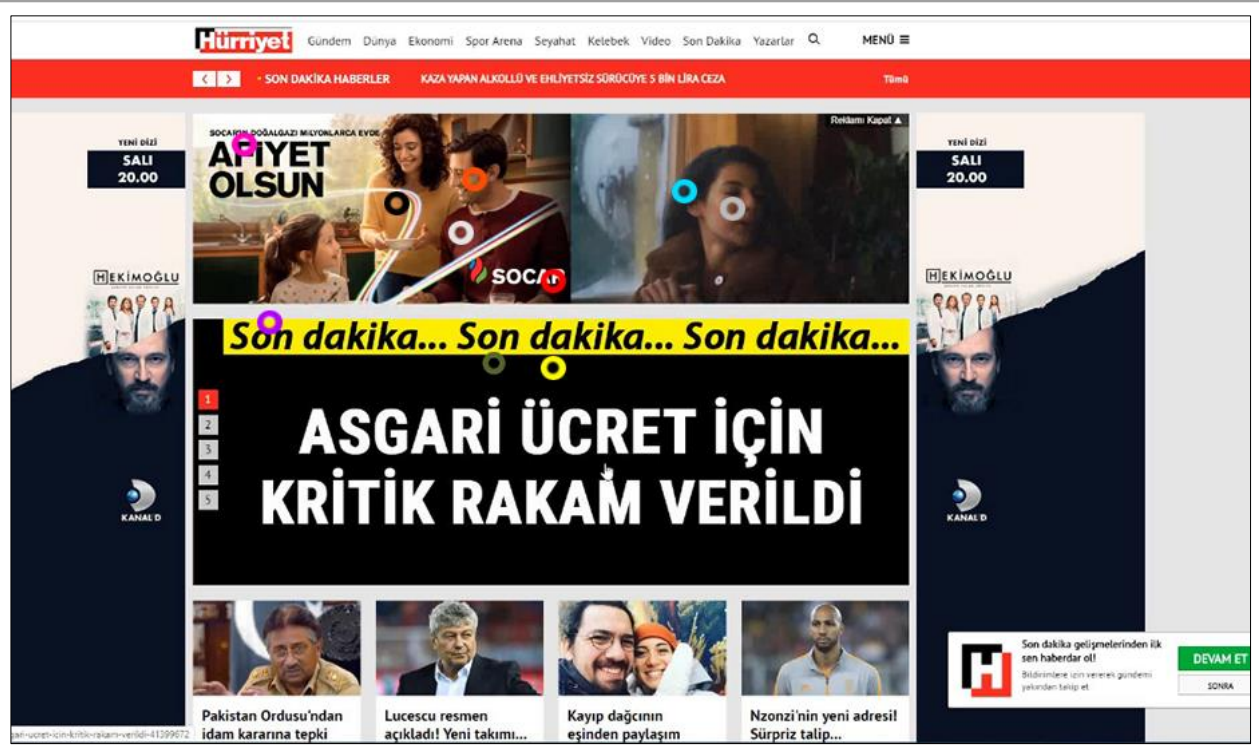

Şekil 2: hurriyet.com.tr'de 10 Katılımcının İlk Bakış Noktası

İlk bakış noktaları Şekil 3'de verilen ensonhaber.com haber sitesinde hurriyet.com.tr'de olduğu gibi katılımcıların büyük bir kısmının sayfanın üst orta bölümüne baktığı görülmektedir. Haber manşetlerinin olduğu 'slider' bölümü, katılımcıların tamamına yakınının ilk bakış noktasını oluşturmaktadır. Sayfayı kaplayan banner reklamların olmaması ve daha sade bir tasarıma sahip olması açısından ensonhaber.com dikkat çekmektedir. ensonhaber.com'da yorum yapabilmek için üyelik gerekmemektedir. Ancak kullanııının yorum şartlarını kabul etmek için işaretlemesi gereken onay kutusu ile kullanıcı adı kutucuğunun yazısının küçük ve silik olması, kullanıcının yorum yapmasını engelleyen veya yorum yaparken zaman kaybettiren noktalar olarak göze çarpmaktadır. Ayrıca deney sürecinde bu onay kutularının, yorum gönderme çabalarının başarısız olmasının ardından kullanıcılar tarafından fark edildiği gözlemlenmiştir. Diğer yandan ensonhaber.com'da göz tarama yolunun genel olarak soldan sağa, yukarıdan aşağıya doğru olduğu görülmüştür.

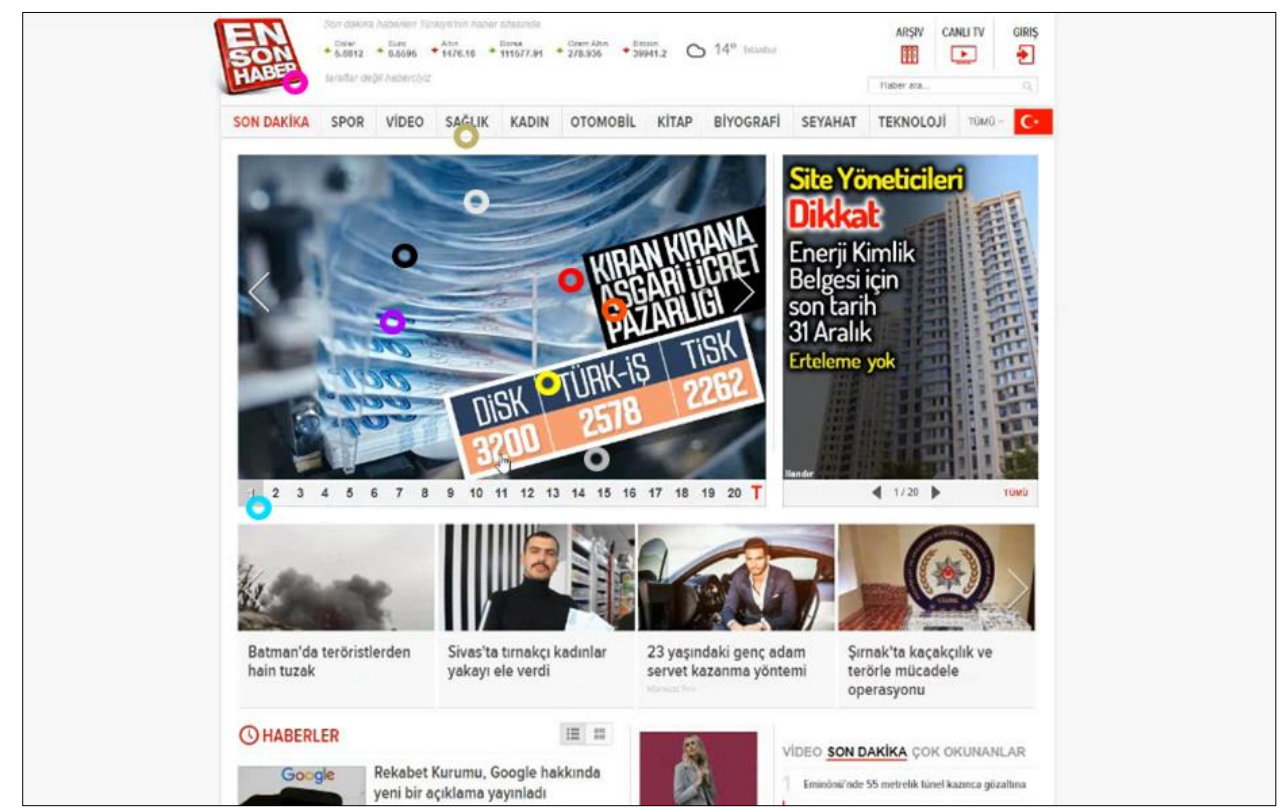

Şekil 3: ensonhaber.com'da 10 Katılımcının İlk Bakış Noktası 
Şekil 4'te haber7.com üzerinde katılımcıların ilk bakış noktaları verilmiştir. Buna göre haber7.com'da katılımcıların ilk bakış noktalarının diğer haber sitelerine göre daha dağınık olduğu görülmektedir. Katılımcıların 6'sının ilk olarak üst manşet 'slider' bölümüne baktığı görülürken 1'i üstteki 'son dakika' bölümüne, 1'i slider altındaki reklama, 1'i soldaki banner reklama, 1'i ise alt slider bölümüne bakmıştır. Dolayısıyla haber7.com'da da hurriyet.com.tr'de olduğu gibi reklamlar katılımcılar üzerinde dikkat çekici bir etki göstermiştir. Katılımcıların haber7.com'daki göz tarama yolu soldan sağa ve yukarıdan aşağıya olmakla birlikte özellikle üst slider altındaki hareketli reklamın göz tarama yolunda sıçramaya neden olduğu görülmüştür.

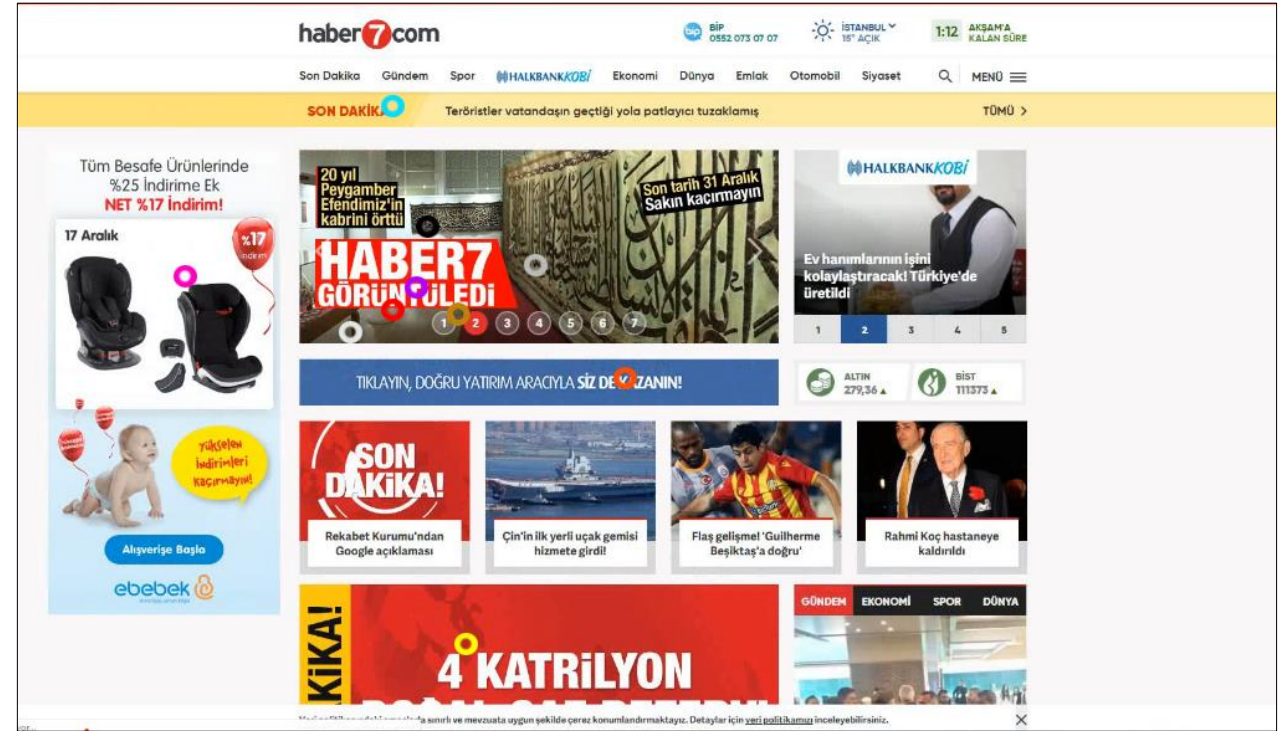

Şekil 4: haber7.com'da 10 Katılımcının İlk Bakış Noktası

Çalışma kapsamında deney sonrası mülakat yapılan katılımcılardan 8'i en zorlandıkları haber sitesinin hurriyet.com.tr olduğunu söylerken 2'si haber7.com olduğunu belirtmiştir. Hem deney verilerine göre hem de mülakat verilerine göre katılımcıların deney sürecinde en çok zorlandıkları ve görevlerin en çok zaman aldığı site hurriyet.com.tr'dir. Katılımcılarla yapılan mülakatta "bu haber sitesinin diğer haber sitelerine kıyasla daha karmaşık ve göz yorucu" olduğu, "yorumda üyelik gerektirmesinin sorun yarattığı", "arşivin ve arşivde haber aramanın işlevsel olmadığı", "reklamların fazla olduğu", "reklamların yer kaplayıcı ve dikkat dağıtıcı olduğu" görüşleri öne çıkmıştır. En çok haber7.com'da zorlandığını söyleyen 2 katılımcıya göre; "sitede yorum bölümünün haber metninin tam altında değil, sayfanın en sonunda yer alması ve görsel açıdan sitenin karmaşık olması" haber7.com'un kullanılabilirliğini olumsuz etkilemektedir. Bu çerçevede katılımcılardan 7'si kullanılabilirlik açısından en olumlu gördükleri haber sitesinin ensonhaber.com, 2'si haber7.com, 1'i ise hurriyet.com.tr olduğunu belirtmiştir.

Katılımcıların haber sitelerinde en rahatsız edici buldukları unsur reklamlardır. Reklamların hareketli olması, sayfada fazla yer kaplaması ve özellikle haber sitelerinde açılır kapanır reklamlara yer verilmesi haber sitesinin tercih edilmesinin önündeki en büyük engel olarak görülmektedir. Diğer yandan pop-up'lar da kullanıcıların rahatsız oldukları bir diğer unsurdur. Haberlerin genellikle alt kısmında bulunan yorum bölümünde yorum yapmanın üyelik gerektirmesi, kabul şartları ve onay kutusunun görülebilir olmaması sitelerde kullanılabilirliğin önündeki engellerdendir. Görsellerin çok büyük olması, arşivin görülebilir olmaması ve arşivde aranan habere ulaşılamaması, incelenen haber sitelerinde kullanıcıların rahatsızlık duyduğu ve sitelerin kullanılabilirliğini düşüren diğer unsurlar olarak öne çıkmıştır. Deney sürecinde reklamların ve pop-upların katılımcıların göz tarama yollarında sıçramalara neden olması bu durumu doğrulamaktadır. Ayrıca katılımcıların haber 
sitelerinde rahatsızlık duydukları hususlar, deney sürecinde görevlerin ya gerçekleştirilememesine neden olan ya da bu görevlerin tamamlanma sürelerini uzatan noktalar olarak dikkat çekmiştir.

\section{Sonuç}

İnternet haberciliğinde ortaya çıkan kullanılabilirlik sorunlarını tespit ederek bu sorunların ortadan kaldırılması ve internet haber sitelerinin daha kullanışlı hale getirilebilmesini için öneriler sunulması amaçlanan çalışmada internet haber sitelerinin kullanılabilirliği göz izleme cihazı yardımıyla kullanıcı ekseninde ortaya konulmuştur. Çalışma Gazetecilik alanında lisansüstü eğitim gören; cinsiyet, yaş ve eğitim durumları bakımından benzer özellikler gösteren 5'i kadın 5'i erkek olmak üzere toplam 10 katılımcı ile gerçekleştirilmiştir. Belirli kriterler üzerinden Ağustos-Eylül 2019 verilerine göre en çok tıklanan 10 haber sitesi arasından seçilen ensonhaber.com, haber7.com ve hurriyet.com.tr'nin kullanılabilirliği ölçülmüştür. Katılımcıların 6 temel görevi gerçekleştirip gerçekleştiremediği ile bu görevlerin gerçekleştirilme süresi ölçülmüştür. Diğer yandan katılımcıların örnek olarak seçilen her bir haber sitesindeki ilk bakış noktası (Bee Swarm), göz tarama yolu (Scan Path) ve tıklama noktaları söz konusu görevlerin yapılabilmesi açısından göz izleme cihazı ile tespit edilmiştir.

Üç haber sitesinde saniye bazında kayıt altına alınan ortalama görev tamamlama süreleri dikkate alındığında katılımcıların en çok zorlandığı ve görevi yaparken zaman kaybettiği iki görev kategorisi yorum yapma ve arşive ulaşma olarak ortaya çıkmıştır. Gerek deney süreci gerekse deney sonrası mülakat sonuçlarına göre bu durum haber sitelerinde arşiv ve yorum bölümünün kolay bir kullanıma sahip olmadığını göstermektedir. Bir kullanılabilirlik sorunu olarak ortaya çıkan bu durum haber sitelerinin erişilebilirlik ve etkileşim özelliklerinin işlerliğine engel olmaktadır.

Görev tamamlama süresi bakımından bir katılımcı hariç tüm katılımcıların görevleri en uzun sürede tamamladığı, bununla birlikte katılımcılar tarafından en karmaşık bulunan haber sitesinin hurriyet.com.tr olduğu görülmüştür. Ayrıca hurriyet.com.tr'de hiçbir katılımcı görevleri diğer haber sitelerine göre daha erken tamamlayamamıştır. Bu haber sitesi üzerinden arayüzün karmaş1k görünümü, büyük görsellerin kullanımı, büyük boyutlu dinamik reklamların dikkat dağıtması ve çok sayıda slider bulunmasının haber sitelerinde kullanılabilirlik sorunları yarattığı sonucunu çıkarmaktadır. Söz konusu kullanılabilirlik sorunlarının yoğunluğu, görevlerin yerine getirilmesinde en çok zaman kaybı yaşanan sitenin de hurriyet.com.tr olmasına neden olmuştur. Bu sorunların daha az görüldüğü haber7.com ve ve ensonhaber.com'un katılımcıların çoğunluğunun tüm görevleri en erken yerine getirdiği siteler olması ve haber sitesi bazında verilen tüm görevlerin ortalama tamamlama süreleri dikkate alındığında, görevlerin en kısa sürede tamamlanabildiği haber sitesinin ensonhaber.com olması bu sonucu doğrulamaktadır. Dolayısıyla hurriyet.com.tr katılımcıların en çok, ensonhaber.com ise en az zaman harcayarak görevleri yerine getirdiği haber siteleri olarak öne çımmaktadır. Bu durum; ensonhaber.com'un, hurriyet.com.tr'ye kıyasla daha daha az kullanılabilirlik sorunlarına sahip olduğunu göstermektedir.

Bee swarm ve Scan path verileri açısından değerlendirildiğinde hurriyet.com.tr'de konumu ve boyutu itibariyle reklam, katılımcıların büyük bir kısmının dikkatini çekmiş ve ilk bakılan nokta olmuştur. Diğer yandan kullanıcıların göz hareketlerinde reklam ve pop-up kısmına doğru sıçramaların olduğu tespit edilmiştir. Bu yönüyle kullanıcının dikkatini çeken hareketlilik gözün haber metinleri ve görsellerden kaymasına neden olurken pop-upların kapatılması gerekliliği tıklama noktalarında sapmalara ve görev sürelerinde uzamaya neden olmuştur. ensonhaber.com'da, haber manşetlerinin olduğu 'slider' bölümü, katılımcıların tamamına yakınının ilk bakış noktasını oluşturmaktadır. Sitede büyük ve dikkat çeken banner reklamların olmaması ve daha sade bir tasarıma sahip olması kullanım kolaylı̆̆ yaratmıştır. Ancak ensonhaber.com'da kullanıcının yorum şartlarını kabul etmek için işaretlemesi gereken onay kutusu ile kullanıcı adı kutucuğunun yazısının küçük ve silik olması, kullanıcının yorum yapmasını engelleyen veya yorum yaparken zaman kaybettiren noktalar olarak öne çıkmıştır. Katılımcıların haber7.com'da ilk bakış noktalarının diğer 
haber sitelerine göre daha dağınık olduğu görülmüştür. Göz hareketleri ve ilk bakış dikkate alındığında haber7.com'da, hurriyet.com.tr'de olduğu gibi reklamların katılımcılar üzerinde dikkat çekici bir etki gösterdiği tespit edilmiştir. Özellikle üst slider altındaki hareketli reklamın, haber7.com'u ziyaret eden kullanıcıların göz tarama yolunda sıçrama yarattığı görülmüştür. Bu açıdan haber sitelerindeki dinamik unsuların dikkat dağıttığı görülmektedir.

Genel olarak göz tarama yolu, ilk bakış noktası, görev süreleri ve mülakat verileri ele alındığında haber sitelerinde kullanılabilirliği en fazla olumsuz etkileyen unsurun reklamlar olduğu görülmüştür. Özellikle deney sonrası katılımcılarla yapılan mülakat verilerine göre; "reklamların hareketli olması", "sayfada fazla yer kaplaması" ve özellikle "haber sitelerinde açılır kapanır reklamlara yer verilmesi" haber sitesinin tercih edilmesinin önündeki en büyük engeller olarak görülmektedir. Ayrıca haber sitelerinde yer alan pop-uplar da kullanıcıların rahatsız olduğu ve bu yönüyle kullanılabilirliği olumsuz etkileyen bir diğer unsur olarak dikkat çekmektedir. Deney sürecinde gerek reklamlar gerekse pop-uplar dikkat dağıtmış ve katılımcıların göz tarama yollarında sıçramalara neden olmuştur. Bu açıdan internet haber sitelerinde daha sade bir tasarımın gerekliliği ortaya çıkarken reklamlar ile pop-upların haberi gölgeleyecek nitelikte olmamasına özen gösterilmesi gerektiği sonucuna ulaşılmıştır. Dolayısıyla haber sitelerinde sayfayı kaplayan, büyük boyutlu, açılır kapanır reklamlar ile pop-up gibi dinamik unsurların daha az kullanılması, kullanılması halinde de haberin önüne geçmeyecek ve dikkat dağıtmayacak nitelikte olmasına özel gösterilmelidir. Ayrıca haber sitelerinde görsel boyutlarının çok büyük olmamasına da özen gösterilmelidir.

Deney sürecinde ele alınan haber sitelerinin genellikle alt kısmında bulunan yorum bölümünde yorum yapmanın üyelik gerektirmesi, kabul şartları ve onay kutusunun görülebilir olmaması da sitelerde kullanılabilirlik sorunu yaratmaktadır. Haber sitelerinde etkileşimin ve dolayısıyla demokratik katılımın sağlanması açısından yorum için üyelik şartının olmaması önemli görülürken yorum kısmının hızlı ve kolay kullanımı temel alan bir tasarıma sahip olması gerekmektedir. Tasarım olarak yorum bölümünün haber metninin hemen altında yer alması, yorum yapabilmeyi kolaylaştıracaktır.

Enformasyon teknolojilerinin haberciliğe getirdiği en büyük avantajlardan biri haberin arşivlenerek saklanabilmesidir. $\mathrm{Bu}$ açıdan haber sitelerinin arşivlerini oluşturmaları, daha sonra $\mathrm{o}$ haberlere ulaşmak isteyen kullanıcılar için işlevsel olacaktır. Dolayısıyla kullanılabilirlik sorunlarından birini oluşturan haber arşivinin kolay bulunamaması ya da arşivde haber bulamama sorununun ortaya çıkması internet haber siteleri açısından önemli bir sorun olarak görülmektedir. $\mathrm{Bu}$ bağlamda ulaşılabilirlik ve tercih edilme açısından arşivin daha görülebilir ve işlevsel bir yapıya sahip olması da haber sitelerinde dikkat gerektiren bir başka nokta olarak öne çıkmaktadır.

\section{Kaynakça}

Acartürk, C., Çağıltay, K. (2006). İnsan Bilgisayar Etkileşimi ve ODTÜ'de Yürütülen Çalışmalar. 8. Akademik Bilişim Konferans1, 9-11 Şubat, Pamukkale Üniversitesi, Denizli.
Alexa.
(t.y.).
Top
Sites
in Turkey.
02.11 .2019
tarihinde https://www.alexa.com/topsites/countries/TR adresinden erişildi.

Brône, G., Oben, B. (2018). "Gaze, Interaction and Eye-Tracking: A Multidisciplinary Endeavor." Eye-Tracking in Interaction: Studies on the Role of Eye Gaze in Dialogue. Ed. Geert Brône - Bert Oben.John Benjamins Publishing Company: 1-18.

Cangöz, İ. (2015). Değişen Anlam ve Değerleriyle Gazetecilik. Ankara: Sınırsız.

Carroll, M. J. (2003). HCI Models Theories and Frameworks Toward a Multidisciplinary Science. San Francisco: Morgan Kaufmann Publishers. 
Çağıltay, K. (2011). İnsan Bilgisayar Etkileşimi ve Kullanılabilirlik Mühendisliği: Teoriden Pratiğe. Ankara: ODTÜ Geliştirme Vakfı Yayıncılık.

Değirmencioğlu, G. (2016). Dijitalleşme Çağında Gazeteciliğgin Geleceği ve İnovasyon Haberciliği. TRT Akademi, 1(2), 590-606.

Dix, A., Finlay, J., Abowd, G.D., \& Beale, R. (2004). Human-Computer Interaction. Harlow: Pearson Education.

Dreyfus, H. L. (2016). İnternet üzerine. (Çeviren: Demir, VM). İstanbul: Küre Yayınları.

Duchowskia, Andrew T. (2002). A Breadth-First Survey of Eye-Tracking Applications. Behavior Research Methods, Instruments, \& Computers. 2002, 34 (4), 455-470.

ensonhaber.com. (t.y.). 11.09.2019 tarihinde https://www. ensonhaber.com adresinden erişildi.

Erdoğan, İrfan (2012). Pozitivist Metodoloji ve Ötesi. Ankara: Erk Yayınları.

Geray, H., Aydoğan, A. (2010). "Yeni İletişim Teknolojileri ve Etik." Televizyon Haberciliğinde Etik. Ed. Bülent Çaplı - Hakan Tuncel. Ankara: Fersa Matbaacılık: 305- 321.

haber7.com. (t.y.). 07.09.2019 tarihinde https://www.haber7.com adresinden erişildi.

hurriyet.com.tr. (t.y.). 06.09.2019 tarihinde https://www.hurriyet.com.tr adresinden erişildi.

Males, L. M., Setniker, A. (2019). Planning with Curriculum Materials: Interactions between Prospective Secondary Mathematics Teachers' Attention, Interpretations and Responses. International Journal of Educational Research. 93, 153-167.

Myers, B. A. (1994). "Challenges of HCI Design and Implementation”. Interactions. 1(1). 73-83.

Nielsen, J. (1993). Usability Engineering. Boston: Academic Press Inc.

Nielsen, J. (2000). Why You Only Need to Test with 5 Users. 01.11.2019 tarihinde https://www.nngroup.com/articles/why-you-only-need-to-test-with-5-users/adresinden erişildi.

Nielsen, J., \& Landauer, T. K. (1993). A Mathematical Model of the Finding of Usability Problems. In Proceedings of the INTERACT'93 and CHI'93 Conference on Human Factors in Computing Systems, (Amsterdam, The Netherlands, 24-29 April). pp. 206-213. ACM.

Pavlik, J. V. (2013). Yeni Medya ve Gazetecilik, (Çev. Berrin K., Müge D.). İstanbul: Phoenix Yayınları.

Stanyer, J. (2009). "Web 2.0 and the Transformation of News and Journalism", Andrew Chadwick ve Philip N. Howard (der.), Routledge Handbook of Internet Politics, New York: Routledge, s.201-213.

Similarweb. (t.y.). Top Websites Ranking. 03.11.2019 tarihinde https://www.similarweb.com/topwebsites/turkey adresinden erişildi.

Tokgöz, O. (2013). Temel Gazetecilik. Ankara: İmge Kitabevi.

Toruk, İ. (2008). Gutenberg'den Dijital Çağa Gazetecilik. İstanbul: Literatürk.

Törenli, N. (2005). Yeni Medya, İletişim Ortamı. Ankara: Bilim ve Sanat Yayınları. 